\title{
Bank Service Complaint Handling: Effects on Bank Customers' Satisfaction in Nigeria
}

\author{
Obasi, Obasi K Abugu, James O Chukwu, Amaechi M \\ Department of Marketing, Faculty of Business Administration, \\ University Of Nigeria Nsukka, Enugu State, Nigeria
}

\begin{abstract}
The study investigated the effects of bank customers' complaints handling on customers satisfaction in the selected Banks in Enugu - Nigeria. Survey method with the aid of questionnaire was used to elicit relevant data from a sample of 357 respondents within the area of the study. Data obtained were presented and analysed using statistical package for social science (SPSS) version 23. The hypotheses for the study were tested and findings showed that Banks responsiveness to complaints by customers, service guarantee and recovery has significant and positive effect on bank customers' satisfaction. It was therefore concluded that service complaints resolutions significantly effect customers' satisfaction positively. The study recommended that organization should exert quick response to customers' complaint, engage in effective guarantee and service recovery to build customers confidence, satisfaction, trust and gain their patronage and loyalty.
\end{abstract}

Keywords: Effects, complaint Handling, responsiveness, guarantee, Service recovery, satisfaction

DOI: $10.7176 / \mathrm{JMCR} / 67-05$

Publication date: April $30^{\text {th }} 2020$

\section{Introduction}

Customers' satisfaction is enhanced when their complaints are properly handled. Every business activity that wishes to succeed should aim at customer satisfaction. A satisfied customer is most likely to be loyal and asset to organization.

Service oriented organizations provide services which are intangible, as a result; listening and handling the customers Complaints is one of the efficient ways of satisfying them. The failure of service organization to provide service quality required by the customers leads to customers' complaints. Uppal (2010) posited that customer complaint arises due to the attitudinal aspects that deals with customers and inadequacy of the arrangement made available to customers or gap standards of services expected and actual services rendered. The customer has the right to register his complaints if he is not satisfied with the service provided by servicebased organizations like the banks. Customers can complain in writing or orally. If customers complaint is not resolved within a given time or if unsatisfied with the solution provided in the context they can approach 'banking Ombudsman' with the complaints for grievances redress. Customers who complain should be seen as partners with the services providers and their complaints should be seen as a tool to improve the services quality, customers' satisfaction and profitability of the organization. Customers' Complaint provide an opportunity to learn about what customers want from a service, thus promoting the serving organization to device means of redress. It may be to meet certain service quality level as required by the customers. Service quality is the total of all that a customer needs from a service. Rai (2013), reported that service quality has been related to customer satisfaction and loyalty. Lovelock and Wirtz (2011) as quoted in Ganesh and Haslinda (2014), reported that the terms "quality" and "satisfaction" are used interchangeably, and some researchers believe that perceived service quality is just one component of customer satisfaction, which also reflects an individual's personal and situational factors.

In today's global business world, it is widely held that how companies respond to customer or consumer complaints have become critical aspects of providing effective customer services that ultimately affect consumers' choices of service (Okyere and Kumadey, 2015). Customers' complaints management is becoming central in customer relationship management and is considered as an essential strategic tool for firms across industries (Strauss \& Hill, 2001). Companies have become increasingly interested in customers' feedback to the extent that dissatisfied customers, in particular, are often encouraged to voice out their complaints to companies' service representatives.

According to Ragavan and Kalaivanan (2016), the banking industry is unique and distinct in one respect that the products offered by the banks are identified with little difference from one to another. That is to say that banks offer similar services. Thus, the product attraction receives less importance, as the products of other banks are identical. The only factor that differentiates a bank from others is how it functions and renders services to the customers.

The effectiveness, efficiency, growth and overall profitability of a bank amongst its competitors, among other things, depend on the level of satisfaction obtained by customers on complaint handling. In the banking sectors, complaint could arise due to long queues, hidden charges, ATM down times, the impolite attitude of 
Banks' staff, among others. These complaints come up often and, ignoring, or delaying the effective handling adversely affect the banks' customers' satisfaction. When a customer's complaint is not properly handled, it mostly leads to loss of the customer who switches to available and presumed better competitor.

On the other hand, when a customer's complaint is properly handled, he is likely to be satisfied and becomes a fan of the organization and good mouth the organization to others. Customers complaint varies and weight attached to each in relations to customers satisfaction is relative. Studies on effect of customers complaints handing on Bank customers satisfaction in Nigeria, to the best knowledge of the researchers is sparse. The researchers therefore hypothesized thus;

- Responsiveness to customers' complaint on unauthorized transaction has no significant positive effect on customers' satisfaction

- Service guarantee as an aspect of complaint handling does not significantly enhance customers' satisfaction

- Service recovery as an aspect of complaint handling has no significant positive effect on customers' satisfaction

\section{LITERATURE REVIEW}

The review cut across concept of service quality, other service dimensions and constructs of the study.

\section{Concept of Service Quality}

Service quality (SQ) is viewed as a crucial issue in the banking industry because of its apparent relationship to customer satisfaction (Jamali, 2007), to profitability (Williams, Ogege \& Ideji, 2014). In the like manner, Ganguli, and Roy, (2011) defined service quality in terms of key dimensions that customers use while evaluating the service provided. Consequently, service quality could be widely regarded as a driver of corporate marketing and financial performance. It can be inferred from these that service quality is commonly noted as a critical prerequisite and determining force in competitiveness and for establishing and sustaining a satisfying relationship with customers since it is an essential indicator of customer satisfaction.

Fry, Stoner and Hattwick (1997) quoted in Goyit, (2015), state that quality has seven dimensions. These are; performance, special features, conformance, reliability, durability, service after the sale and perceived quality. Performance relates to the primary operating features of a product or service which can be objectively measured on individual on aspects of performance, i.e. how well a product performs or how well a service is provided. Special features are those added extras that affect or enhance the appeal or performance of the product or service offered to the user but are not standard on all competing products or services. Conformance, relates to how well a product performs compared to consumers' expectations. Reliability refers to the consistency of performance; can the service always be expected to perform the way it should? Durability relates to the life of the service. Perceived quality is almost as important as quality itself. However, customers also have perceptions of quality based on advertisements, past experiences and competing products/services. The perceived quality is outstanding because it affects customer expectations. Gong and Yi (2018) reported that customers satisfaction was due to service quality.

Goyit, (2015) quoting Crosby (1984) opined that quality means conforming to requirements. ISO defines quality as the totality of characteristics of an entity that bear on its ability to satisfy stated and implied needs. From these definitions, a marketer delivers quality when the services meet or exceed the expectations of the customer. The emphasis should be the prevention of quality of service problem rather than just the correction of quality problems. It is worthy of mention to stress here that improving the quality of service can be the driving force to improving results in other parameters.

In an attempt to give a clearer picture of service quality, Goyit, (2015) categorised service quality into two dimensions, namely:

- Technical quantifiable aspects, e.g. standard of equipment, producer's knowledge and other measurable aspects. These are dimensions that are relatively quantifiable aspects of a service which customers receive in their interactions with a service firm. They can be measured by both customers and suppliers, and this often forms a significant basis for the judgment of the quality of services. For example, the time spent in waiting to be attended to by a bank cashier, supervisor, restaurant waiter, or the reliability of an ATM device. These form an essential basis for measuring or judging service quality provided by service firms.

- Functional aspects of service quality. These aspects cannot be measured quite objectively as those of the technical dimensions of service quality. Examples include the attitude of staff, the appearance of staff and atmosphere/environment of suppliers practice.

To probably reduce the difficulty in defining service quality, it is safer to view it from two perspectives, namely:

i. Producers or Providers perspective, and

ii. Customer perspective 


\section{(1) Service Delivery Failures}

This category consists of three types of failures:

$>$ Unavailable service- this refers to services that are lacking or absent, for example, fully booked hotel.

$>$ Unreasonably slow service- relates to services or employees that customers perceive as being extraordinarily slow in fulfilling their function. For example, lengthy queues at the enquiries counter in the bank. Receiving low service quality as against expected higher quality from the bank. (Ibrahim, et al 2015).

$>$ Other, core service failures- this category is broad and reflects the various core services offered by different industries. For example, food service, baggage handling, that are at times not properly served or not available.

(2) Failure to respond to customer needs and requests

This category involves non responses to individual needs and requests of customers,

(3) Unsolicited and unprompted employee action

The third type of service failure arises from employee behaviours that are unexpected by the customers. Ennew and Schoefer (2003) identify the categories of this group as;

- Negative level of attention to customers: This pertains to employees who have poor attitudes, ignore a customer and have behaviour inconsistent with an indifferent attitude. Unusual actions: The unusual behaviour subcategory includes employee actions such as rudeness, abusiveness and inappropriate touching.

- Cultural norms: The cultural norm subcategory refers to actions that violate cultural norms such as fairness and equality.

- Gelstat: This subcategory refers to customer evaluations that are made holistically as in the case of a customer who evaluates a holiday resort as dissatisfying without identifying any specific incidents that cause this dissatisfaction.

- Adverse conditions: Finally, the adverse condition subcategory covers employee actions under stressful conditions, for example, customers are impressed by an employee who takes effective control of situation when all others around him are 'losing their heads. Organizations need to identify and understand the type of service failure they experience in order to appropriate recovery strategy and develop future policies to limit the occurrence of such service failures.

\section{Understanding Customer Complaints}

Complaints are natural consequence of any service activity because "mistakes are unavoidable feature of all human endeavour and thus of service delivery". Boshoff (1997)cited in Wasfi and Kostento, (2014). The process of putting the situation right is service recovery (Berry \& Parasuraman, 1991). Customer complaints are probably the most effective way of collecting information to put the situation right (Ennew and Schoefer, 2003). Unfortunately, many customers do not complain following a service failure but do engage in activities such as negative word-of-mouth (infect others with negative reports) and brand switching (defection). This means that many organizations may miss out. It is recognized that complaints are necessary to institute service recovery. Without complaints, a firm may be unaware that problems exist and unable to appease unhappy customers.

There are four complaint response groups, namely, passives, voicers, irates and activists. Passives fall below average on intentions to complain to any source. Voicers actively complain to service providers but show minimal interest. In providing negative word-of-mouth, irates have high tendency to complain to service providers and less likely to engage third-party actions. Finally, activists are customers who score above average on all complaint dimensions (Mupemhi et al., 2012).

\section{Benefits of Excellent Complaint Management}

- Excellent complaint management can lead to levels of cumulative satisfaction that are higher than existing before service failure. Effective complaint handling can lead to higher levels of customer loyalty; increased patronage, a higher level of customer retention and higher profitability index (Johnston, 2001; Mupemhi et al., 2012).

- Excellent complaint management will increase not only overall satisfaction but also positive word-ofmouth. This means that customers who were recovered successfully recommend the company to others.

- Loyal customer may Lower marketing costs since retaining customers is usually significantly cheaper than attracting new ones.

- A key benefit of complaint management is that complaints can be used to support the drive for continuous improvement by focusing managerial attention on specific problem areas.

- Good systems to reduce complaints include 'doing things right the first time'. This calls for employee empowerment. Employees need to have control over work situations. This leads to less stress, and in 
turn job satisfaction, organisational commitment, better job performance and health, and this will have a direct impact on the organisation's performance.

Responsiveness to Customer's Complaints on Disputed and Unauthorized Transactions

Unauthorized transactions are the transactions without the customers consent. It also includes standing order which the customer has cancelled, yet the bank went ahead to treat it mistakenly. When considering customer complaints about disputed and unauthorized transactions, we take into account, the followings:

- The relevant law;

- Any regulations that applied at the time in question;

- Any industry codes of conduct in force at the time in question; and

- The terms and conditions of the account that the disputed transaction was made from.

If there is a disagreement about the facts, the bank will make their own decision about what probably happened, using the information and evidence provided by the customer and the financial business, and any additional information that they discover from their investigation of the complaint. Depending on the nature of the complaint, and the type of transaction being disputed, the banks are likely to ask for these sorts of things:

- Information about the regular pattern of use for the account in question;

- The "journal roll" of the cash machine used to make the disputed transaction;

- Records for the paying-in machine used to make the disputed transaction;

- Information about the business's standard process or procedure;

- Information about any identity or security checks made in connection with the disputed transaction;

- The consumer's recollection of where they were, or what they were doing, at the time of the disputed transaction;

- Samples of the consumer's signature;

- Website screen-shots or emails associated with the disputed transaction;

- Copies of any paperwork relating to the disputed transaction.

The responsiveness of the bank in handling unauthorized transaction to a reasonable extent makes bank customer to be satisfy. Effective complaint handling has the greater value in creating customers' satisfaction. (Salim A, Setawan, M, Rofiaty, R and Rohman, F, 2018). On a solution to ATM frauds in Nigeria Adeoti (2011) profer that bank employ customized software that required relevant information on ATM card so that the banks can establish whether unauthorized transaction has taken place or not.

\section{Service Guarantee and customers Satisfaction}

Service is crucial for restoring customer satisfaction and for encouraging repatronage following under service or a service failure. Service guarantee can be provided through organizational efforts, such as a compensation that offsets costs incurred by the customer, a timely resolution of the failure, and polite interpersonal treatment (Roschk and Kaiser, 2013). Although employees are instrumental in delivering recovery, organizational policies such as service guarantees, can pose a constraint to employee efforts and, in turn, influence customer perceptions of recovery fairness. For example, a customer may perceive recovery as unfair if the compensation for a delivery lost in the past does not at least cover for the cost of the service, or it is lower than the level set in the policy.

Service guarantees are frequently used by companies across sectors, such as hospitality, banking and professional services (e.g., Co-operative Bank's guarantee on customer service, Royal Mail's guarantee on delivery services). The prevalence of service guarantees has spurred conceptual and empirical studies examining the characteristics of service guarantees and the impact of these policies on consumer perceptions and behaviour. In this regard, Hart (1988) proposed the precepts of service guarantee policies, whilst Ostrom and Iacobucci (1998) investigated the role of service guarantees in shaping customer satisfaction and quality perceptions. Following from the above studies, several other issues relating to service guarantees have been examined, for instance, the influence of guarantees on customer preferences (McDougall et al., 1998) and perceptions of risk (Wirtz and Kum, 2001), service guarantee as a signaling mechanism (McCollough and Gremler, 2004), the impact of guarantees on customer cheating intentions (Wirtz and Kum, 2004), customer choice of the service provider (Wu et al., 2012), and purchase decisions (Jin and He, 2013).

Berman and Mathur, (2014) suggested that recovery implemented through service guarantees can reduce negative word of mouth. Further, Björlin-Lidén and Edvardsson (2003) noted that customers are concerned about the fairness of service guarantees and are suspicious of guarantee policies introduced in an effort to increase customer acquisition rates. However, the above studies do not examine customer perceptions of fairness and inferences about the firm's motives for introducing this guarantee, when this policy is implemented as a recovery strategy.

In a recent study, Van Vaerenberg et al. (2014) investigated how employee recovery efforts shape customer intentions towards invoking service guarantees. In the above study, service recovery and guarantees are treated as two distinct strategies and customer perceptions of justice are not examined. 
In practice, through service guarantees, a company pledges compensation and lays down the procedures for claiming the compensation in the event of service failure (i.e. guarantee terms). These two guarantee terms, in turn, signal the firm's fairness in attempting recovery, and the firm's intentions for offering the policy. The signaling effect of guarantee terms can be seen as consistent with the well-established Signaling Theory (Spence, , 2002). Prior research suggests that, in their role of signals, service guarantees convey information about the quality attributes of the service (Chen et al., 2009).

Further, customers evaluate the information signaled by the guarantee terms, and they draw inferences about the firm's motives for offering the policy. For example, Kukar-Kinney et al. (2007) suggest that customers infer the firm's motives from the specific terms set in the policy, which in turn influence justice perceptions. Such inferences represent attributions for the intentions or motives underlying the firm's actions, termed 'inferred motive'. Based on the valence of inferred motives (positive or negative), customers form perceptions as to whether the guarantee terms are fair or unfair. For instance, when receiving small guarantee payout in the form of a discount rather than full refund, customers may view the firm as pursuing its own interests of profits (negative motive), rather than serving the customer interests (positive motive). In such instances, customers may feel treated unfairly. Perceptions of unfairness may in turn lower intentions to repatronize the firm. Extant service recovery research has so far overlooked inferred motive, despite the relevance.

\section{Service Recovery as Complaint Handling}

Service recovery can be defined as an action undertaken by the service provider in response to service failure (Grönroos, 1990) in an attempt to deliver service right at the second trial Lovelock and Wirtz, (2011) reported that 'Service recovery is an umbrella term for systematic efforts by a firm to correct a problem following a service failure and to retain a customer's goodwill". Service recovery is a broad concept that is regarded as a proactive customer retention tool; Bendall-Lyon and Powers (2001) opined that complaint handling is a significant part of service recovery and is majorly characterised by the following actions:

- Encouraging complaints to enhance service quality;

- Creating a special complaint handling department ;

- Ensuring a quick and fast response to lodged complaints

- Installing a complaint database

- Affirming that all unsatisfactory service encounters are identified;

- Using compliant database for tracking trends for further improvements

Essentially, intangible nature of services makes it challenging to understand and meet customers' expectations. Meanwhile, increasing the likelihood of errors which can take place both from operational and consumer's perspectives (Parasuraman, Zeithaml and Berry, 1991 cited in Mupemhi et al., 2012). Giving this dynamic, conducting business in service industry implies elaboration of systematic approach for effective complaint handling.

In this notion, consistent with Thwaites and Williams (2006) it is five times more expensive to attract new customers rather than retaining existing ones. Additionally, disappointment with the offered service may lead to spreading negative word of mouth, this idea is further reinforced by the findings of Sousa and Voss (2009) and Morrisson and Huppertz (2010) who claimed that, dissatisfied customers may tell from ten to twenty people about their bad experience, whereas if the problem is resolved successfully, it is usually shared amongst up to five people on average.

Miller et al. (2000) divided complaint handling strategies into two types: psychological and tangible strategy. The psychological approach is focused on actions like explaining the problem to the customer and apologising whereas, in this case, the emphasis is applied on communication; meanwhile, the tangible approach is concentrated on refunding and material compensation.

Berry and Parasuraman (1991) emphasized the prominence of functional dimension in complaint handling process and pointed out that the outcome is more essential while delivering original service; yet it can depend on the type of service at the point.

The findings of previous studies in the service recovery field are arguable. For instance, some studies argue that effective complaint handling can enhance customer satisfaction higher than if no failure has occurred in the first place, so-called "service recovery paradox. However, other scholars such as Sousa and Voss (2009) pointed out that effect of service recovery paradox does exist but not substantial, whereas as cited in Mupemhi et al., (2012) rejected entirely significant impact of effective complaint handling on customer satisfaction and loyalty.

\section{Theoretical Framework}

The study was based on relevant theories that delve into the constructs to give support to the findings of the research. 


\section{Equity Theory}

Equity theory proposes that a person's motivation is based on what he or she considers to be fair when compared to others (Redmond, 2010 cited in Wood (2016). Equity theory when applied to service complaints handling focuses on a customer's compensation in relation to service failure as well as the customer's attempt to minimize any sense of unfairness that might result.

Consumers are prone to spread a negative word-of-mouth when they perceive an unfair response to a service failure. When customers perceive that they have not been sufficiently compensated for the damage, they may feel even more annoyed than they were, subsequent to the failure. This is because a report of a service failure may imply unfair treatment of the customer. Service recovery must therefore re-establish justice - from the customers' perspective. With effective handling of complaints, consumers will perceive fair treatment. In the case of a service failure, individuals will perceive inequity, and they will try to restore equity by complaining. According to Gruber (2011), complaining customers develop their equity or fairness perceptions by evaluating three facets of the complaint handling encounter: the fairness of the decision making criteria, procedures and policies used to accomplish the final outcome (procedural justice), the fairness of the obtained tangible outcomes (distributive justice) and the interactional justice or manner in which the service complaint handling process is carried out (Tax et al., 1998). Equity theory seems quite tenable in a service failure context because consumers usually perceive an inequity following a service failure. When inequities arise, equity theory provides a meaningful framework for shaping consumer perceptions of satisfaction, purchase intent and favorable word-ofmouth.

\section{Perceived Justice Theory}

Researchers consider theories of organizational justice to explain customers' reactions to service recovery. Justice perceptions are the individual subjective assessments of organizational responses. The subjective evaluation of the response of the complainant is crucial because perceptions are the subjective, often biased, interpretation of reality that accounts for individual behaviour (Geibrich \& Roschk, 2010). Blodgett and Anderson (1994) contend that prior research demonstrates that the behaviour of complainants depends mainly on their perceptions of justice. Complainants who perceive that justice is not served likely become even angrier, engage in negative word-of-mouth and exit (Tax et al., 1998).

Distributive justice is outcome justice. It focuses on equity issues in the mind of the customer - an appraisal of the benefits received relative to the costs (money and time) associated with them. When the organization does not deliver an expected benefit, leading to a sense of being unfairly treated, this necessitates recovery. In recovery, customers may expect a refund, an apology, or/and compensation (Michel et al., 2009). Distributive justice involves dealing with decision outcomes; namely, the principles of equity and equality. Every customer who initiates a complaint expects some outcome to result from it, and it is the expectation of positive outcomes that drives consumer complaint decisions. Most often, however, dissatisfied consumers want a refund, replacement, or compensation when they complain, and most studies of post-complaint, satisfaction show that distributive justice in the form of compensation has the most significant impact on customer satisfaction with recovery, repurchase intentions and loyalty. Interactional justice refers to how customers perceive the way they are treated; treatment is perceived as fair when complainants assume that information is exchanged and outcomes are communicated politely and respectfully. A complainant procedure is considered fair when it is allegedly easy to access, provides the complainant with some control over the disposition, is flexible and is concluded in a convenient and timely manner, (Gelbrich \& Roschk, 2010).

Customers should be treated as individuals whose specific requests are acknowledged. Employee subjective cognition on customer's behaviour would reflect directly on the service recovery for the customers (Lin, 2009) Procedural justice refers to process fairness and the evaluation of the procedures and systems used to determine customer outcomes, such as the speed of recovery (Tax et al., 1998) or the information communicated (or not communicated) about the recovery process (.Michel, 2002). Procedural justice involves dealing with decision-making procedures or having a complaint procedure the customers perceive as fair. Consumer evaluation of the interaction dimension suggests that the quality of the interpersonal treatment and communication during the encounter are likely to be heavily weighted by consumers when evaluating service encounters.

Complainants consider all three-justice needs to evaluate the effectiveness of the organization's complaint handling the effort, but interactional justice takes centre stage. Karatepe and Ekiz (2004) concluded that interactional justice has a stronger impact on satisfaction than the other two justice dimensions. Interactional justice may be a more critical moderator of reactions to unfairness than procedural or distributive justice. Both the immediacy and transparency of social interactions make it relatively easier for the customer to assign moral accountability when contact employees violate interactional justice principles.

Gelbrich \& Roschk (2010) indicated that customers would be satisfied with a partial refund if they were treated kindly and respectfully. Customers who were treated unpleasantly would not continue the relationship 
with the retailer and would engage in negative word of mouth even in the case of a total refund (Geibrich \& Roschk, 2010). This stresses the importance of understanding how dissatisfied customers want to be treated by contact employees during the complaint handling encounters.

In the view of Davidow (2003) the distinctiveness of the three justice dimensions has been called into question. They made a report on high correlations between justice dimensions. Ligo et al., (2003) adds that perceived justice has a higher order latent variable in confirmatory factor analysis using this construct as a single predictor of post-complaint satisfaction. Duffy et al., (2006) include the justice dimension in one latent variable in their confirmatory factor analysis (CFA) arguing that, customers use a compensatory model when forming an overall perception of justice.

A possible reason for the poor discriminate validity is that consumers are unable to clearly distinguish between a favourable outcome and respectful treatment. Whether the three justice dimensions have distinctive antecedents and consequences that aid in deriving implications for marketing practitioners is questionable. Complainants consider the three justice needs to evaluate the effectiveness of the organization's service recovery efforts, but interactional justice takes centre stage. Furthermore, Blodgett \& Anderson (2000) discovered that high levels of interactional justice could offset lower levels of distributive justice.

\section{MATERIAL AND METHODS}

\section{Research Design}

The research design was survey method.

\section{Area of the Study}

The study was conducted at Enugu state, Nigeria. Enugu state is made up of three senatorial districts; namely Enugu East senatorial district, Enugu West senatorial district and Enugu North Senatorial District.

The population of the study is the customers of the three selected banks from each of the three senatorial districts of Enugu State. It was estimated that each of the banks has daily average customers they attend to. The target population of the study was the total of the daily average customers attendance for each bank. The daily average customers attendance for the banks under review are: First Bank Nigeria PLC main branch Okpara Avenue 2400 (daily transaction) Enugu East Senatorial distinct, Polaris Bank Udi Branch, 600 (daily transaction) Enugu West Senatorial district, Access bank PLC Enugu Road branch Nsukka, 800 ( daily transaction) Enugu North Senatorial district.

The sample size of 367 was determined using the Taro Yamane Formular.

The instrument for data collection was the questionnaire structured in Likert scale to enable respondents indicate the extent to which they agree/disagree with each statement concerning the bank customers complaints handling and satisfaction.

Data presentation and analysis

The researchers presented and analysed the data that mainly concerned the study constructs.

Table 1: Distribution of Respondents views on bank's responsiveness to complaints about unauthorised transactions and information on relevant laws as it concerns unauthorised transaction.

\begin{tabular}{|l|c|c|}
\hline Variable & Frequency & Percentage(\%) \\
\hline SD & 25 & 7.0 \\
\hline D & 50 & 14.0 \\
\hline U & 52 & 14.6 \\
\hline A & 133 & 37.3 \\
\hline SA & 97 & 27.1 \\
\hline Total & $\mathbf{3 5 7}$ & $\mathbf{1 0 0}$ \\
\hline
\end{tabular}

Source: Field Survey, 2019

The respondents' view of their bank's' responsiveness to their complaints about unauthorized transactions and relevant laws as it concerns unauthorized transactions are shown in the above table, 25 customers representing $7.0 \%, 50$ representing $14.0 \%$ and 52 representing $14.6 \%$ of the respondents strongly disagreed, disagreed and are undecided respectively on the fact that their banks respond to their complaints about unauthorized transactions in relative to relevant laws on unauthorised transactions. Consequently, 133customers representing $37.3 \%$ and 97 representing $27.1 \%$ agreed and strongly agreed respectively to the fact. 
Table 2: Respondents views of bank's responsiveness to complaint on unauthorized transaction for purpose of indemnifying.

\begin{tabular}{|l|c|c|}
\hline Variable & Frequency & Percentage(\%) \\
\hline SD & 16 & 4.5 \\
\hline D & 34 & 9.5 \\
\hline U & 46 & 12.9 \\
\hline A & 166 & 46.5 \\
\hline SA & 95 & 26.6 \\
\hline Total & $\mathbf{3 5 7}$ & $\mathbf{1 0 0}$ \\
\hline
\end{tabular}

Source: Field Survey, 2019

The table above shows that 16 customers $(4.5 \%), 34(9.5 \%)$ and $46(12.9 \%)$ of the respondents strongly disagreed, disagreed and are undecided respectively that banks respond to their complaints about the unauthorized transaction by calling for the records of the paying in machine used to make the unauthorized transaction and getting them indemnified consequently, 166(46.5\%) and 95(26.6\%) of them agreed and strongly agreed

Table 3: Respondents views on whether banks has service guarantee policy, pledges compensations in the event of service failure.

\begin{tabular}{|l|c|c|}
\hline Variable & Frequency & Percentage (\%) \\
\hline SD & 44 & 12.3 \\
\hline D & 37 & 10.4 \\
\hline U & 64 & 17.9 \\
\hline A & 133 & 37.3 \\
\hline SA & 79 & 22.1 \\
\hline Total & $\mathbf{3 5 7}$ & $\mathbf{1 0 0}$ \\
\hline
\end{tabular}

Source: Field Survey, 2019

The table above shows that 44 Customers (12.3\%), 37(10.4\%) and 64(17.9\%) of the respondents strongly disagreed, disagreed and are undecided respectively on whether there is a form of service guarantee policy, pledges, compensations in the event of service failure. Whereas $133(37.3 \%)$ and $79(22.1 \%)$ of them agreed and strongly agreed respectively to that fact.

Table 4:Respondents view on banks identification and rectification of all unsatisfactory service encounters.

\begin{tabular}{|l|c|c|}
\hline \multicolumn{1}{|c|}{ Variable } & Frequency & Percentage(\%) \\
\hline SD & 12 & 3.4 \\
\hline D & 37 & 10.4 \\
\hline U & 110 & 30.8 \\
\hline A & 133 & 37.3 \\
\hline SA & 65 & 18.2 \\
\hline Total & $\mathbf{3 5 7}$ & $\mathbf{1 0 0}$ \\
\hline
\end{tabular}

Source: Field Survey, 2019

The table above shows that 12 customers(3.4\%), 37(10.4\%) and $110(30.8 \%)$ of the respondents strongly disagreed, disagreed and are undecided respectively on the fact that their banks aim at service delivery by affirming that all unsatisfactory service encounters are identified and rectified, whereas 133(37.3\%) and $65(18.2 \%)$ of them agreed and strongly agreed respectively.

\section{Test of Hypotheses}

Hypothesis one

$\mathrm{H}_{1}$ : Responsiveness to customers' complaints on unauthorized transactions does not significantly and positively effect on customers' satisfaction.

\section{Model Summary}

\begin{tabular}{|l|r|r|r|c|}
\hline Model & $\mathrm{R}$ & R Square & \multicolumn{1}{c|}{$\begin{array}{c}\text { Adjusted R } \\
\text { Square }\end{array}$} & $\begin{array}{c}\text { Std. Error of the } \\
\text { Estimate }\end{array}$ \\
\hline 1 & $.498^{\mathrm{a}}$ & .248 & .246 & .80161 \\
\hline
\end{tabular}

a. Predictors: (Constant), Responsiveness to a customer complaint on the unauthorized transaction 


\begin{tabular}{|ll|r|r|r|r|r|}
\hline \multicolumn{7}{|c|}{ ANOVA $^{\mathbf{a}}$} \\
\hline Model & & Sum of Squares & Df & Mean Square & \multicolumn{1}{c|}{ F } & Sig. \\
\hline 1 & Regression & 73.602 & 1 & 73.602 & 114.541 & $.000^{\mathrm{b}}$ \\
& Residual & 222.977 & 347 & .643 & & \\
& Total & 296.579 & 348 & & & \\
\hline
\end{tabular}

a. Dependent Variable: Customer's satisfaction

b. Predictors: (Constant), Responsiveness to customer's complaint on the unauthorised transaction

Coefficients ${ }^{\mathrm{a}}$

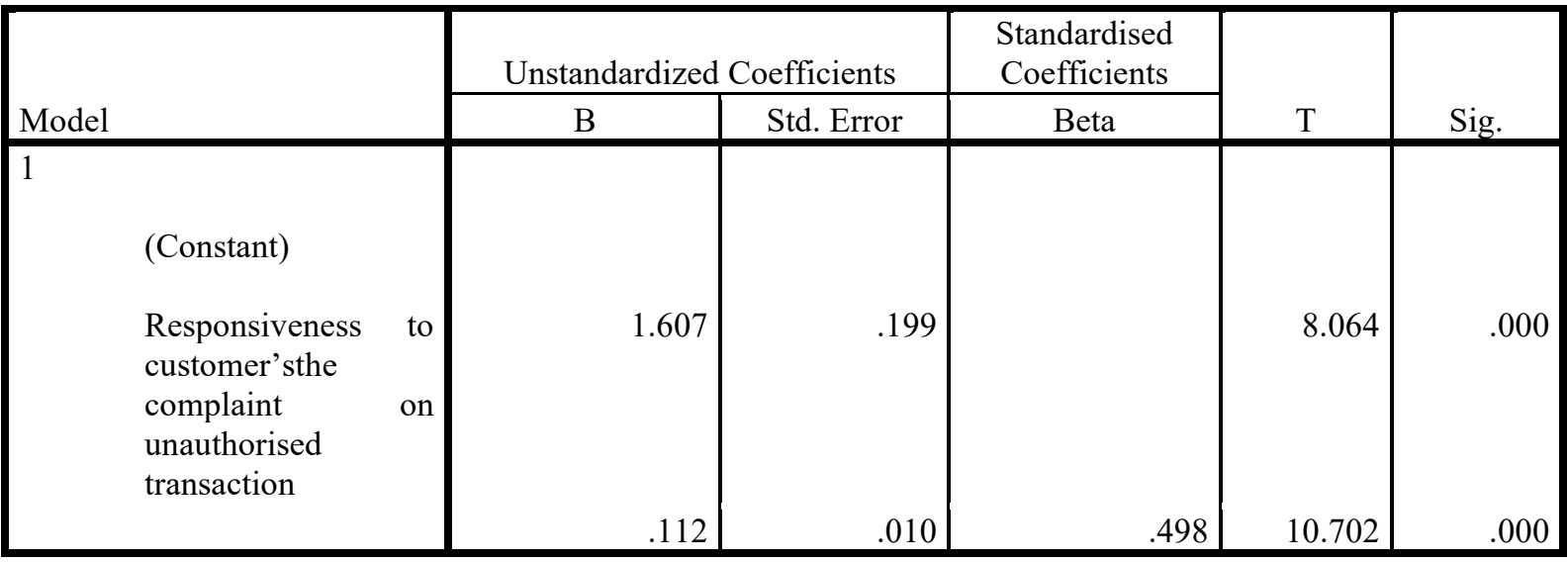

a. Dependent Variable: Customer's satisfaction

The model summary table shows that the correlation coefficient $(\mathrm{R})$ of 0.498 indicates a weak linear positive relationship between responsiveness to customer's complaint on unauthorised transaction and customers' satisfaction. A coefficient of determination $\left(\mathrm{R}^{2}\right)$ of 0.248 indicates that $24.8 \%$ of the variation that exists in customer's satisfaction can be explained by timely resolution of the complaint. The ANOVA results show an overall significance. The coefficient table shows that responsiveness to customers' complaint on unauthorised transaction has a significant positive effect on customers' satisfaction $(\mathrm{P}<0.001, \mathrm{~B}=0.112)$. Responsiveness to customer's complaints on unauthorised transactions significantly and positively effect customers satisfaction.

\section{Hypothesis Two}

$\mathrm{H}_{2}$ : Service guarantee as an aspect of complaint handling does not significantly enhance customers' satisfaction.

Model Summary

\begin{tabular}{|l|r|r|r|r|}
\hline Model & R & \multicolumn{1}{|c|}{ R Square } & Adjusted R Square & Std. Error of the Estimate \\
\hline 1 & $.693^{\mathrm{a}}$ & .481 & .479 & .67132 \\
\hline
\end{tabular}

a. Predictors: (Constant), service guarantee

ANOVA ${ }^{\mathrm{a}}$

\begin{tabular}{|ll|r|r|r|r|r|}
\hline Model & & Sum of Squares & df & Mean Square & F & Sig. \\
\hline 1 & Regression & 141.503 & 1 & 141.503 & 313.980 & $.000^{\mathrm{b}}$ \\
& Residual & 152.779 & 339 & .451 & & \\
& Total & 294.282 & 340 & & & \\
\hline
\end{tabular}

a. Dependent Variable: Customer's satisfaction

b. Predictors: (Constant), service guarantee

\begin{tabular}{|c|c|c|c|c|c|c|}
\hline & & \multicolumn{2}{|c|}{ Coefficients $^{\mathrm{a}}$} & \multirow[b]{2}{*}{$\begin{array}{l}\text { Standardised } \\
\text { Coefficients }\end{array}$} & \multirow[b]{3}{*}{$\mathrm{T}$} & \multirow[b]{3}{*}{ Sig. } \\
\hline \multirow[b]{2}{*}{ Model } & & \multicolumn{2}{|c|}{ Unstandardized Coefficients } & & & \\
\hline & & B & Std. Error & Beta & & \\
\hline 1 & (Constant) & .807 & .167 & & 4.834 & .000 \\
\hline & Service guarantee & .191 & .011 & .693 & 17.719 & .000 \\
\hline
\end{tabular}


The model summary table shows that the correlation coefficient $(\mathrm{R})$ of 0.693 indicates a strong linear positive relationship between service guarantee and customers' satisfaction. A coefficient of determination $\left(\mathrm{R}^{2}\right)$ of 0.481 indicates that $48.1 \%$ of the changes in customers' satisfaction can be attributed to Service guarantee. The ANOVA results show an overall significance. The coefficient table shows that Service guarantee has a significant positive effect on customers' satisfaction $(\mathrm{P}<0.001, \mathrm{~B}=0.191)$. Therefore, Service guarantee as an aspect of complaint handling significantly enhances customers' satisfaction.

\section{Hypothesis three}

$\mathrm{H}_{3}$ : $\quad$ Service recovery as an aspect of the complaint handling process does not significantly enhance customer's satisfaction.

Model Summary

\begin{tabular}{|l|r|r|r|r|}
\hline Model & R & \multicolumn{1}{|c|}{ R Square } & Adjusted R Square & Std. Error of the Estimate \\
\hline 1 & $.163^{\mathrm{a}}$ & .027 & .024 & .91295 \\
\hline
\end{tabular}

a. Predictors: (Constant), Service recovery

ANOVA

\begin{tabular}{|ll|r|r|r|r|r|}
\hline Model & & Sum of Squares & Df & Mean Square & F & Sig. \\
\hline 1 & Regression & 7.762 & 1 & 7.762 & 9.313 & $.002^{\mathrm{b}}$ \\
& Residual & 283.384 & 340 & .833 & & \\
& Total & 291.146 & 341 & & & \\
\hline
\end{tabular}

a. Dependent Variable: Customer's satisfaction

b. Predictors: (Constant), Service recovery

\section{Coefficients ${ }^{\mathbf{a}}$}

\begin{tabular}{|l|r|r|r|r|r|}
\hline \multirow{2}{*}{ Model } & \multicolumn{2}{|c|}{ Unstandardized Coefficients } & Standardised Coefficients & & \multirow{2}{*}{ Sig. } \\
\cline { 2 - 6 } & \multicolumn{1}{c|}{ B } & Std. Error & Beta & 15.587 & .000 \\
\hline 1 (Constant) & 3.102 & .199 & & 3.052 & .002 \\
\hline
\end{tabular}

a. Dependent Variable: Customer's satisfaction

The model summary table shows that the correlation coefficient $(\mathrm{R})$ of 0.163 indicates a weak linear positive relationship between service recovery and customer's satisfaction. A coefficient of determination $\left(\mathrm{R}^{2}\right)$ of 0.027 indicates that $2.7 \%$ of the variation that exists in customer's satisfaction can be explained by service recovery. The ANOVA results show an overall significance. The coefficient table shows that service recovery has a significant positive effect on customer's satisfaction $(\mathrm{P}=0.02, \mathrm{~B}=0.028)$. Hence the null hypothesis is hereby rejected and the alternative accepted. Therefore, Service recovery as an aspect of the complaint handling process significantly enhances customer's satisfaction.

The model summary table shows that the correlation coefficient $(\mathrm{R})$ of 0.163 indicates a weak linear positive relationship between service recovery and customer's satisfaction. A coefficient of determination $\left(\mathrm{R}^{2}\right)$ of 0.027 indicates that $2.7 \%$ of the variation that exists in customer's satisfaction can be explained by service recovery. The ANOVA results show an overall significance. The coefficient table shows that service recovery has a significant positive effect on customer's satisfaction $(\mathrm{P}=0.02, \mathrm{~B}=0.028)$. Hence the null hypothesis is hereby rejected and the alternative accepted. Therefore, Service recovery as an aspect of the complaint handling process significantly enhances customer's satisfaction.

\section{Discussion of Findings}

The result from hypothesis one revealed that responsiveness to customers' complaint on unauthorized transactions has significant and positive effect on customers satisfaction. This receives the support of Salim, et al (2017) that banks needed to manage customer complaint in order to satisfy them and increase retention.

The result from the test of hypothesis two indicates that service guarantee as an aspect of complaint handling significantly enhances customers' satisfaction. This is in line with the study by Kerr (2004) cited in Shammout and Haddad (2014). Similarly, it is in line with the outcome of the study of carried out by Shammout and Haddad (2014) which show that there is a statistically effect impact of service guarantee on the customers' satisfaction.

The result from test of hypothesis three showed that service recovery as an aspect of the complaint handling strategy significantly enhances customer' satisfaction. This is supported by some studies that argue that effective complaint handling can enhance customer satisfaction higher than if no failure occurred in the first place, so- 
called "service recovery paradox" (Wasfi and Kostenko,2014). It is in line with Vutele et al (2015) who were of the opinion that the inevitability of service failure in banks and other services business is putting customer complaints and service recovery systems at the centre of survival core competencies and to ensure effective complaint handling and customer satisfaction. Commercial banks need to understand the reactions and feelings of the concerned customers on their previous service failure and recovery encounter.

\section{Conclusion}

Based on the findings, the researchers concluded that efficient and effective complaint handling significantly and positively effect customers' satisfaction. Essentially, responsiveness to complaint about unauthorized transactions, service guarantee and service recovery aspects of the complaint handling strategies were established to enhance customers' satisfaction. Customers' complaints should be seen and treated as an essential task and opportunity for service providers; like banks to discover areas for improvement which will result to customers' satisfaction and organizational growth.

\section{Recommendations}

1. Banks and similar businesses should ensure quick responses to customers' complaints. This can be achieved by having a centralized complaint handling department and giving the complainants update from time to time until the complaints are finally resolved.

2. Banks should include and implement service guarantee in their customer service policies.

3. Banks and businesses that engage in service delivery should ensure that service recovery, which involves compensation to complainants forms part of service charter of businesses in Nigeria. In this case, there should be a written policy that communicates commitment to doing business with customers', and this will define the purpose, scope and the standard of commitment to customers' service so that both the staff and customers know what to expect.

4. The banks' complaint handling processes and procedures should be subject to adequate monitoring to ensure that customers' complaint are met thereby resulting to satisfaction. The processes should be subject to internal audit which in addition to the identification of procedural exceptions should also examine the accessibility of complaint handling, the quality and promptness of decision made and the reports being submitted to senior management. Banks may also resort to other techniques such as research inform of mystery shopping or consumer satisfaction surveys to ascertain the performance of complaint handling and improve where possible.

\section{References}

Adeoti, J. O. (2011) Automated Teller machine (ATM) Frauds in Nigeria: The way out JSOC SC, 27(1): 33 58.

Bendall - Lyon, D and Powers, T. L. (2001), "The Role of Complaint Management in Service Recovery Process in Joint Commission" Journal on Quality and Patient Safety Vol 27, No 5 pp 278 -286

Bendall-Lyon, D and Powers, T.L ( 2001) "The Role of Complaint Management in Service Recovery Process" Joint Commission Journal on Quality and Patient Safety Vol 27 No 5 PP278 -286

Berman, B and Mathur, A (2014) Planning and implementing effective service guarantee programs Business Horizons Vol 57 No1 PP107-116

Berry, L. L and Parasuraman, A ,(1991), "Marketing Services: Competing through quality". Free Press, New York.

Bjorlin-Liden, S and Edvardson , B (2003) Customer Expectations on service guarantees Managing Service Quality Vol 13 No5 PP338-348

Boshoff, C. (2005), "Are - assessment and Refinement of RECOVSAT; An instrument to Measure n Marketing Service Quality", Vol 15 No 5 pp $410-425$.

Chen, X.J, John, G, Hays , J. M., Hill ,A.V and Geurs, S.E.,(2009) Learing from a service guarantee quasi experiment Journal of Marketing Research Vol 46 No5 PP584-596

Cronrros, C. (1984). A service quality model and its marketing implication. European Journal of Marketing Vol 18 , No 4 PP $36-43$

Davidow, M (200) Organizational Responses to Consumer Complaints: What works and what doesn't.. Journal of Service Research vol 5 no 3 Pp 225 -250.

Duffy, J. M. Miller, J. M, And Bexley, J. B (2006) Banking Customers' Varied reactions to Services Recovery Strategies. International Journal of Bank Marketing Vol 24 No 2 Pp 112 - 32

Ennew, C. T. and Schoefer, K. (2003). Customer Evaluation of Tour Operations Responses to their Complaints: An exploratory study. Journal of Travel and Tourism Marketing

First Bank Nigeria Feedback and Complaints policy Retrieved Online from https: firstbanknigeria. com/home/contactas/ feedback-and-complaints. 
Gelbrick ,K and Roschk, H (2010). A Meta Analysis of Organizational Complaint handling and customer responses. Journal of service research Vol $1 \mathrm{pp} 1-20$

Gong, T and Yi Youjae (2018) the Effect of Service quality in customer satisfaction, Loyalty and happiness in five Asian Countries, Psychology and marketing 35(6)

Goyit, M (2010). Building a Global Competitive advantage through quality Management. The Nigeria Journal of Management Research Vol 1.

Goyit, M. G (2015) Service Quality and Financial Performance of selected Banks in Nigeria (2006 - 2013) A Thesis presented to the Department of Business Administration, faculty of Management Sciences University of Jos.

Gronroos C (1990) Service Management and Marketing: Managing the Moments of Truth in Service Competition, Lexington Book Massachusetts.

Gruber, T (2011), "1 want to believe that they really care: How Complaining customers wants to be Treated by Frontline employees. Journal of Service Management Vol 22 No 1 PP 85 -110

Hart ,A (1998). The Power of unconditional service guarantee Harvard Business Review July -August PP52-62

Ibrahim, Y, Adem, M. and Gigiorgis, H (2015). Analysis of factors affecting service quality; A survey study in bank of Abyssinia alula Abanega branch, Mekella, Ethopia, Int'l journal of management and social science research 4:36-43.

Jamali; D (2007). A study of Customer Satisfaction in the Context of a public Private partnership. International Journal of Quality and Reliability Management Vol 24 No, 4 PP 370 - 383.

Johnston, R (2001). Linking Complaint Management to Profit. Journal of Service Industry Management Vol 12 No 2

Katakepo, O. M and Ekiz, E. H (2004) The Effect of organizational Responses to Complaints on Satisfaction and loyalty: Case of Hotel Quests in Northern Cyprus. Journal of Managing Service quality Vol 14, No 6 Pp $476-86$.

Kukar-Kinney, M., Xia, L. and Monroe, K.B., (2007). Consumers Perceptions of the fairness of price-matching refund policies. Journal of Retailing Vol 83 No3 PP325-337

Ligo, S. H, Cheng, C. H, Liao, W. B and Chen, I. L (2003). A web architecture for Implementing electronic procurement in Military Organization. Technovation vol. 23 PP $531-532$.

Lin, W. B (2009) Service Recovery Model; An Integrated View. The Service Industry Journal 29(5) pp.669 -691.

Love Lock, C. H and Wirtz, J (2011). Service Marketing, People, Technology Strategy (7 ${ }^{\text {th }}$ edn). Boston, Prentice Hall

Michel , S., Bowen , D., and Johnston, R (2009). Why Service recovery fails: Tensions among ustomers, Employee and Process Perspectives. Journal of Service Management Vol 20 No3 pp 253-273

Miller, J. L, Graighead, C. W and Karwan, K. R (2000). Service Recovery a Framework and Empirical Investigation. Journal of Operational Management Vol 18 No 44 PP 387 - 400.

Morrisson O and Huppertz, J. W (2010). External quail, Loyalty Program Membership and Service Recovery. Journal of Service marketing vol 24 No 3 PP $244-254$.

Mupemhi, S ., Mupemhi, R and Feremba J.T. (2006). Understanding service failure and complaint management in marketing oriented organisation. Journal of Services Marketing Vol 21 No 3 .

Okyere, O. I. and Kumadey, G. (2015). An assessment of Services and Customer Complaints Management in the delivery of Healthcare in the Municipal Hospitals in Ghana. International Journal of Business and Marketing Management, Vol 3 No2 pp 31-42

Ostrom, A. L and Lacobucci, D. (1998). The effect of guarantee on customers evaluations of services. Journal of Service Marketing Vol 12 No5 PP362-378.

Palmer, A (2005). Principles of service Marketing. Madenhead: McGraw-Hill

Parasuraman, A., Zeithaml V. A and Berry L. L (1991). A multiple-item scale for measuring Consumer Perceptions of Service quality. Journal of Retailing vol 64 No 1 PP $12-37$

Ragavan, N. and Kalaivanan, G. (2016). Customer satisfaction towards the services provided by Commercial Banks-An Analysis. International Conference on "Research Avenues in Social Sciences" organizes by SNGC, Coimbatore. Vol-1, issue 3, pp 2395-4396.

Rai, K., A.. (2013). Customer Relationship Management: Concept and cases (2 ${ }^{\text {nd }}$ Edn). New York: McGrawHill

Salim, A. Setiawan, M. Rofiaty, R, Rohman F (2017) How to build satisfaction and consumer loyalty with a focus on complaints handling (Review of the scientific literature) Journal of financial and banking Review 2 (2) $28-33$

Salim, A, Setiawan M, Rfiaty, R and Rohman F (2018) focusing on Complaints Handling for Customer Satisfaction and loyalty; The case of Indonesian Public Banking European Research studies journal volume XXI, issue 3, 2018.

Shammout, M. Z and Haddad, S. (2014). The Impact of complaint handling on customer's satisfaction: Empirical 
study on Commercial bank's clients in Jordan. Journal of Retailing Vol 13 No 3.

Sousa, R. and Voss, C. A. (2009). The Effect of Service Failures and Recovery on Customer Loyalty In eservices: An Empirical Investigation. Journal of operations Management, vol 29, No 8 PP $834-64$.

Spence, A. M. (1973). Job Market Signaling. The Quarterly Journal of Economics Vol 87 No 3 PP 355-374

Spence, A.M. (2002). Signaling in retrospect and the informational structure of markets. American Economic Review Vol 92 No 3 PP434-459

Strauss, J. and Hill, D. J. (2001). Consumer Complaint by Email: An Exploratory Investigation of Corporate Responses and Customer Reactions. Journal of Interactive Marketing, Vol 15 No 2 PP: 63-72.

Tax, S. S., Brown, S. W, and Chandrashekaran, M. (1998). Customer Evaluations of Service Complaint Experiences; Implications for Relationship Marketing. Journal of Marketing Vol 62 PP 60-76.

Uppal, R. K. (2010). Customer Complaints in Banks: Nature, extent and strategies to Mitigation. Journal of Economics and International Finance vol 2 No 10 pp $212-220$.

Vutete, L., Itumeleng, M, and Wadzanayi, K. I. (2005). Customer perception of service recovery and Complaints handling efforts by Commercial Banks in Zimbawa. Journal of Business and Management, volume 17 No 7 pp $98-107$.

Wasfi, H. and Kostenko, O. (2014) The Impact of Complaint Management on Customer retention; a study of Barking Industry in Sweden and Lebanon a Master's Thesis submitted to the Department of Business Education and Economic Studies University of Gavle.

Williams, H. T., Ogege, S., and Ideji J. O. (2014). An Empirical Analysis of effective Customer Service on Nigerian Banks Profitability: A queuing and Regression approach. Asian Economic and Financial Review Vol 4 No 7, PP $864-87$

Wirtz,J and Kum, T. (2004). Designing service guarantee: Is full satisfaction the best you can guarantee? Journal of Marketing Vol 15,No 4,pp282-299

Wu, C. H, Liao, H. C., Hung, K. P and Ho, Y. H, (2012). Service guarantee in the hotel industry: Their effects on customer risk and service quality perceptions. International Journal of Hospitality Management.

Yang, Z. \& Peterson, R. (2014). Customer perceived value, satisfaction and loyalty: The role of switching cost. Psychology and Marketing, 21,99-822. 